\title{
Brief Review on Fungal Endophytes
}

\author{
Rohit Shankar Mane ${ }^{1}$, Padmaa Milaap Paarakh², Ankala Basappa Vedamurthy ${ }^{(\mathbb{D})^{*}, 3}$ \\ 1,3P.G. Department of Microbiology and Biotechnology, Karnatak University, Dharwad 580 003, Karnataka, \\ India \\ ${ }^{2}$ Department of Pharmacognosy, The Oxford College of Pharmacy, Bengaluru 560 068, Karnataka, India
}

\begin{abstract}
Fungal endophytes are the critical organisms in the environment residing in the plant tissues without showing any harmful effects on its host life cycle. The finding of fungal endophytes in natural habitat has been insufficient due to some non-sporulating and non-culturable fungal endophytes by traditional method. Several investigations on fungal endophytes in plants have resulted in an excessive knowledge of the group. This review emphasis on the biology of fungal endophytes, their discovery, isolation, identification by morphological and molecular methods, production, purification and structure elucidation of the bioactive compounds.
\end{abstract}

\section{INTRODUCTION}

In present scenario, we are dealing with different emerging diseases in our society due to rehabilitated environment and life style. Several researchers are working on the different emerging diseases to understand and cure them by using different natural and chemical formulations however still many areas are untouched due to poor knowledge, techniques and myths $[1,9,12,31,47,57]$. One such area is fungal endophytes. As far as fungal endophytes are concerned, researchers failed to explain their potential medicinal applications in emerging disease $[19,37,47,57,61]$. Some attempts are made to purify fungal endophytes from natural habitats though not effective as compared to other microbes [41,42]. Researchers are trying to isolate new bioactive compounds from newer species of fungal endophytes for medicinal, agricultural and industrial applications though they are unable to explain their origin, pathways

CONTACT: A. B. Vedamurthy $\square$ vedamurthybt@gmail.com @ P.G. Department of Microbiology and Biotechnology, Karnatak University, Dharwad 580 003, Karnataka, India. 
and mechanism of actions $[4,17,27,46,48]$. The need of the hour is to encourage researchers to isolate novel bioactive compounds $[1,2,4,5,6,7,28,34,45,61]$.

The finding of novel bioactive compounds involves isolation, structural elucidation and knowing the biosynthetic pathway of the secondary metabolites. This is an area of significant curiosity to scientists due to the structural diversity, complexity and various bioactivities of isolated compounds $[7,16,42,59]$. Crude natural products have been used unswervingly in drugs manufacturing which forms the basis for deriving semi-synthetic natural products $[13,16,50,51]$.

The objective of this review is to acquaint the researcher with information about the biology of fungal endophytes, and in particular, on the aspects of endophyte research.

\section{HISTORY}

Ecosystem has fungi as significant module. Certain critical practices in ecosystems such as transportation of nutrients from one environment to other, decomposition, recycling etc. are carried out by fungi. Diverse evaluations suggest that the earth may be hosting more than a million fungal species and approximately $3 \%$ have been truly identified [10,46,50] which constitute the second largest cluster of tropical ecosystems of the world. Since they are heterotrophic, they have saprophytic or parasitic association with the hosts. However, in the path of evolution, the fungi developed various types of relationships with them. One of these associations is 'endophytes' [10,12,37]. The fossil archives shows that plants are linked with endophytic and mycorrhiza fungi for approximately 400 million years and most doubtless they were associated when plants started colonizing the land, thus they played a very lengthy and vital role in the evolution $[10,42,50,51]$.

In 1866, De Barry introduced the term "endophyte" for those microbes that reside inside the healthy tissues of plants without causing any apparent diseases [12]. Carroll (1986) coined the term 'endophyte' for those organisms that causes asymptomatic infections within the plants [12]. Petrini (1979) elucidated Carroll's definition as a commensalism in plants [37]. Wilson (1995), further expanded endophytes and included both fungi and bacteria as a commensals [39,53]. Stone et al. (2004) have defined endophytes as "infections are inconspicuous, the infected host tissues do not show symptoms at least for transient period and the microbial colonisation can be demonstrated to be internal." This definition attributes the tenure endophyte to a short-lived grade. It may therefore include an accumulation of microorganisms with dissimilar life history approaches as well as latent pathogens and virulent pathogens in the premature stages of infection $[16,47]$.

Inappropriately, if we take the correct definition, it can include all pathogens at some stage of their development. Therefore, additional characteristic of "not causing apparent harm" as described by Petrini is important as it refers to reflect the lack of macroscopically visible symptoms. Nowadays this term is prolonged as endophytic microorganisms, which includes fungi and bacteria with Actinomycetes, resides intra or intracellularly for their whole or at least part of life cycle $[3,4,5,6,7,9]$.

In $20^{\text {th }}$ century, extensive work has been carried out for the isolation of fungal endophytes from temperate and rainforest region plants because of their largest tropical biodiversity $[10,11,13,17,58]$. Although most studies are on flowers, leaves and stem as compared to bark, fruits, roots and seeds [5,30,31,41]. In Indian natural therapy and Ayurveda, seeds, bark, fruits and roots have been proved safe and natural remedies for different aliments therefore one can go for bark, fruits, roots and seeds in the view of fungal endophytes purification $[2,6,7]$. 


\section{ENDOPHYTISM}

Darwin proposed the idea that diversity can have tough effects on ecosystem practices. Many hypothetical models and investigational test revealed important functions for diversity including the improvement of primary efficiency, nutrient holding, nutrient flow, water availability and resistance to pathogen invasion $[8,9,21]$. The diversity of fungal endophyte is confirmed not only in the specificity of the hosts and their morphology, but also in the types of assistances that they offer to the host. Today fungal endophytes have been isolated from plants ranging from large trees, palms, sea grasses and even from lichens. The numbers of strains and species of endophytes vary drastically and generally depend on the concentration of the research study $[11,12,13,28,46]$.

In general, very little information is available about distributions and factors affecting the shape of fungal endophytes at local and regional level $[14,15,43,44]$. However research has been focussed on relative importance of host and habitat features in shaping local level. As far as tropical endophytes are considered different abiotic factors such as humidity, ultra violet radiation, desiccation and density of leaf litter play a major role [16,18].

It is expected, that the collection of endophytes from a selected plant species is an association of diverse ecological groups of fungal endophytes. For occurrence, fantasy is that at least some of the fungal endophytes endure to survive in the dead leaf tissue as leaf litter decomposers. Long ago, it is reported that some of the foliar endophytes of the mangrove Rhizophora apiculata continue to rise in dropped leaves and produce extracellular enzymes, which act on wall polymers of plant cells. Several research endorse that some fungal endophytic species are also litter decomposers $[19,21,22,60]$ and they have capacity to remain as saprotrophs in dropped leaves. Endophytism represents a stage of fungal endophytes which surrogates between a saprotrophic and an endophytic lifestyle. Spores of such biphasic fungal endophytes in forests undergoing periodic ground fires unveil constitutive heat tolerance proving this hypothesis [20,51].

Expression of unambiguous genes during endophytic and saprotrophic phases have been observed for a root endophyte [23,24,58,61]. Comparable genomic studies are required to question whether multi-host endophytes, which were not subjected to host-guided specialization, have also evolved as an endophyte saprotroph biphasic directly by expressions of specific genes $[8,25,59,61]$.

\section{ISOLATION OF FUNGAL ENDOPHYTES}

Isolation of fungal endophytes is the critical procedure as far as plant selection and impingement methods are concerned. One should understand the criteria used for the plant selection and methods.

\subsection{Criteria for selection and identification of plants}

The criteria used for the selection and identification of plants by the local peoples have been investigated by researcher [25,26,]. Thus, currently there are mainly two hypotheses for the selection of plants namely apparent and non-apparent. Apparent hypothesis involves shrubs and trees while non- apparent deals with only herbs. Apparent plant species produces high molecular weight organic compounds with low toxicity while non-apparent plants harvests low molecular weight organic compounds with high toxicity and bioactivity $[27,29,32]$.

Criteria used for selection and identification of plants are as follows [33,37,41,42,4831].

1. Plants from a distinctive ecological environmental niche, and growing in unusual habitats and holding novel strategies for survival should be considered. 
2. Plants with an ethno botanical antiquity, and used for traditional medicines should be designated for study, as squatting endophytes may be the source of the medicinal stuffs of this plant.

3. Plants that are widespread, having an unusual longevity, or have occupied a certain prehistoric land mass, are suitable for study.

4. Plants growing in areas of great biodiversity have the prospective for housing endophytes with prodigious multiplicity.

5. Plants enclosed by pathogen-infected and showing no symptoms are gatehouse for endophytes.

6. Fresh plant tissue is fit for isolation than older tissues, which often contain many other fungi that make isolation of slow growing fungi easy.

Which part of plants is effective for fungal endophytic research? Somehow, the answer for this question is under debate. According to literature, not only leaves, flowers and fruits are effective but also stem and roots are effective in the view of ethnobotany and pharmacognosy.

The collected plant samples are stored at $4{ }^{\circ} \mathrm{C}$. Isolation should be carried out as soon as possible after collection to avoid contamination by air microspore (Bacon \& White 1994).

After the selection of plants, one can go for authentication with consultation with experts and voucher specimens to be deposited in a herbarium [41,42,48,58].

\subsection{Surface sterilization of selected plant parts.}

In laboratory, plant materials are surface sterilized with surface sterilants as shown in Table 1, 2, 3 and 4. After sterilization, samples are dried and used for isolation process. The species of host plant, and host tissue type sampled and surface sterilization procedures vary according to the investigator. Some investigators have compared carefully the effects of different surface-sterilization procedures [36,40,43], isolation medium and sample-unit size [10] on isolation frequencies. We recommend that investigators experiment with these factors prior to initiating detailed investigations so that protocols optimal for recovery of endophytes from individual host species or specific organs and tissues can be established. For root tissues, serial washing may be preferable to surface sterilization to obtain demonstrative frequencies of fungal colonists $[34,35,46]$.

Table 1. Surface sterilization method used for selected plant samples $(1,2,3,4,30,37,41,53]$.

\begin{tabular}{|l|l|l|l|l|}
\hline \multirow{2}{*}{$\begin{array}{l}\text { Plant } \\
\text { samples }\end{array}$} & \multicolumn{4}{|l|}{ Sterilants immersion duration (seconds) } \\
\cline { 2 - 5 } & Running tap water & $70 \%$ Ethanol & $\begin{array}{l}4 \% \text { Sodium } \\
\text { Hypochlorite }\end{array}$ & Distilled water \\
\hline Leaves & 300 & 30 & 60 & 60 \\
\hline Flowers & 300 & 30 & 60 & 60 \\
\hline Roots & 300 & 30 & 60 & 60 \\
\hline Stem & 300 & 30 & 60 & 60 \\
\hline Fruits & 300 & 30 & 60 & 60 \\
\hline
\end{tabular}

Table 2. Surface sterilization method used for selected plant samples [7,24,27,28,61].

\begin{tabular}{|l|l|l|l|}
\hline \multirow{2}{*}{$\begin{array}{l}\text { Plant } \\
\text { samples }\end{array}$} & \multicolumn{3}{|l|}{ Sterilants immersion duration (seconds) } \\
\cline { 2 - 4 } & $70 \%$ Ethanol & $0.5 \%$ Sodium Hypochlorite & Distilled water \\
\hline Leaves & 180 & 60 & 60 \\
\hline Stem & 180 & 60 & 60 \\
\hline Seeds & 180 & 60 & 60 \\
\hline
\end{tabular}


Table 3. Surface sterilization method used for selected plant samples [25,31,34,45].

\begin{tabular}{|l|l|l|l|}
\hline \multirow{2}{*}{ Plant samples } & \multicolumn{3}{|l|}{ Sterilants immersion duration (seconds) } \\
\cline { 2 - 4 } & Running tap water & $75 \%$ Ethanol & Distilled water \\
\hline Leaves & 300 & 30 & 60 \\
\hline Flowers & 300 & 30 & 60 \\
\hline Roots & 300 & 30 & 60 \\
\hline Stem & 300 & 30 & 60 \\
\hline Fruits & 300 & 30 & 60 \\
\hline
\end{tabular}

Table 4. Surface sterilization method used for selected plant samples [50,51,55,59].

\begin{tabular}{|l|l|l|l|l|}
\hline \multirow{2}{*}{$\begin{array}{l}\text { Plant } \\
\text { samples }\end{array}$} & Sterilants immersion duration (seconds) \\
\cline { 2 - 5 } & Running tap water & $70 \%$ Ethanol & $10 \%$ Commercial bleach & 95\% Ethanol \\
\hline Leaves & 300 & 120 & 120 & 30 \\
\hline Flowers & 300 & 120 & 120 & 30 \\
\hline Roots & 300 & 120 & 120 & 30 \\
\hline Stem & 300 & 120 & 120 & 30 \\
\hline Fruits & 300 & 120 & 120 & 30 \\
\hline
\end{tabular}

\subsection{Methods for isolation of fungal endophytes}

\subsubsection{Isolation by cutting of selected plant parts}

Surface sterilized plant samples are dissected under sterilized conditions into small pieces $(0.2 \mathrm{~cm} \mathrm{X} 0.21 \mathrm{~cm})$ and placed on selected artificial media at room temperature $[27,31,37,34,38,40]$.

\subsubsection{Isolation by Blender shaft}

Surface sterilized plant samples were added to $250 \mathrm{ml}$ of distilled water in beaker and shredded with blender shaft with solvent. Such shafted extract further spread on artificial media for the growth of endophytic fungi $[21,38,45,55]$.

\subsubsection{Isolation by Mortar and Pestle}

To the surface sterilized plant sample, add $1 \mathrm{ml}$ of distilled water and $1 \mathrm{~g}$ of sterile sand into mortar and crushed with a pestle. Resulting suspension were spread on artificial media for further growth of endophytic fungi [54,55,56].

Table 5. Media used for isolation of fungal endophytes

\begin{tabular}{|l|l|l|}
\hline Media Name & Composition (g/L) & References \\
\hline $\begin{array}{l}\text { Wickerham } \\
\text { medium }\end{array}$ & $\begin{array}{l}\text { Malt extract 3, Peptone 5, Yeast extract 3, Glucose } \\
10 \mathrm{pH}-7.2\end{array}$ & {$[41,45,60]$} \\
\hline SAB & Peptone 10, Dextrose 20, agar 15 & {$[3,11]$} \\
\hline YM agar & Malt extract 10, Yeast extract 2, Agar 20. & {$[48,55]$} \\
\hline CYA & $\begin{array}{l}\text { Czapek 10, Yeast extract 5, Sucrose 30, } \mathrm{K}_{2} \mathrm{HPO}_{4}, \\
\text { Agar 15 }\end{array}$ & {$[21,24,46]$} \\
\hline YES & $\begin{array}{l}\text { Sucrose 150, Yeast extract 20, } \mathrm{MgSO}_{4} .7 \mathrm{H}_{2} \mathrm{O} \quad 0.5, \\
\text { CuSO }\end{array} .5 \mathrm{H}_{2} \mathrm{O} 0.005, \mathrm{ZnSO}_{4} .7 \mathrm{H}_{2} \mathrm{O} 0.01$. & {$[31,54]$} \\
\hline MEA & $\begin{array}{l}\text { Malt extract 30, Peptone 5, agar 15, 15, } \\
\text { Chloramphenicol 0.1 }\end{array}$ & {$[33,43,53]$} \\
\hline PDA & Potato 200, Dextrose 20, agar 15 & {$[2,3,4,5,112,1341,42,60]$} \\
\hline
\end{tabular}




\section{IDENTIFICATION OF FUNGAL ENDOPHYTES}

Morphological identification of endophytic fungi by mycologists is a very critical step $[26,48,54]$. It includes development of fungus on standard media, examination of sexual reproduction and determination of growth characteristics. In recent years, according to taxonomical groups, few tests were added such as sub culturing, quick test for purity, examination of sexual reproduction, conidiogenesis and estimation of radial growth and media temperature $[2,3,26,43]$.

Further reference sequences can be created from this identified culture $[47,48,49,53]$. The axenic culture is disinfected and Sequencing the ITS barcode and a subsequent NCBI Gen Bank BLAST search provide a match with an accessioned sequence. Further, fungal DNA extracted from the needles and ITS barcodes are amplified using different platforms such as NGS (e.g: Illumina MiSeq platform). A bioinformatics pipeline processes raw sequence reads and designates OTUs. Sequence does not result in an identification; e.g: $100 \%$ match with unidentified endophyte sequence or no similar sequences present in database $[27,28,54,58]$.

Briefly, molecular characterization of isolated fungal endophytes can be carried out by isolation of genome DNA, PCR amplification of ITS regions, DNA sequencing and sequences analysis $[43,46,53,57,59]$.

Table 6. Fungal endophytes isolated from various plants

\begin{tabular}{|c|c|c|}
\hline Host plant & Identified Endophytic fungus & References \\
\hline Oryza sativa & $\begin{array}{l}\text { Alternaria alternata, Cladosporium tenuissimum, } \\
\text { Epicoccum purpurescens, Fusarium equiseti, F. } \\
\text { oxysporum, Hymenula cerealis, Phoma sorghina, } \\
\text { Pleospora herbarum, Pythium sp., Trematosphaeria sp., } \\
\text { Fusarium sp. Penicillium sp. Aspergillus sp. } \\
\text { Paecilomyces sp. Pyricularia Sacc, Helminthosporium } \\
\text { sp. Yeast, Sterile mycelium. }\end{array}$ & {$[15,31,37]$} \\
\hline Manilkara bidentata & $\begin{array}{l}\text { Xylaria sp., Colletotrichum crassipes, Pestalotiopsis } \\
\text { versicolor }\end{array}$ & {$[, 4,6,27]$} \\
\hline $\begin{array}{l}\text { Lycopersicon } \\
\text { esculentum }\end{array}$ & $\begin{array}{l}\text { Alternaria alternata, Colletotrichum gloeosporioides, } \\
\text { Cladosporium sp., Penicillium sp., Arthrinium sp., } \\
\text { Chaetomium globosum, Colletotrichum coccodes, } \\
\text { Nigrospora sphaerica, Phomopsis sp., Ulocladium } \\
\text { alternariae, Stemphylium botryosum }\end{array}$ & [25] \\
\hline Taxus cuspidate & Alternaria sp. & {$[31]$} \\
\hline Nothapodytes foetida & Neurospora sp. & [2] \\
\hline Camellia sinensis (Tea) & 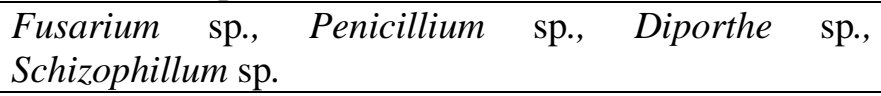 & {$[2,6,31,56]$} \\
\hline Coffee & $\begin{array}{l}\text { Aspergillus, Bipolaris, Cladosporium, Clonostachys, } \\
\text { Colletotrichum, Epicoccum, Fusarium,Guignardia, } \\
\text { Mycospharella, Phomopsis, Rosellinia, Talaromyces, } \\
\text { Trichoderma, Xylaria }\end{array}$ & {$[42,46]$} \\
\hline Quercus variabilis & $\begin{array}{l}\text { Aspergillus sp., Penicillium sp., Alternaria } \\
\text { Cladosporium sp., }\end{array}$ & {$[56,59]$} \\
\hline Azadirachta indica & $\begin{array}{l}\text { Phomopsis oblonga, Cladosporium cladorsporioides, } \\
\text { Pestalotiopsis sp, Trochoderma sp., Aspergillus sp., } \\
\text { Periconia, Stenella, Drechslera }\end{array}$ & {$[30,48,51]$} \\
\hline Huperzia serrata & Acremonium sp. & {$[26,27]$} \\
\hline Ananas ananassoides & Muscodor crispans & {$[32,58]$} \\
\hline Jatropha curcas & Leptosphaeria sp. & {$[44,52]$} \\
\hline
\end{tabular}


Table 6. Continues.

\begin{tabular}{|c|c|c|}
\hline $\begin{array}{l}\text { Paris polyphylla var. } \\
\text { Yunnanensis }\end{array}$ & $\begin{array}{l}\text { Fusarium, Gliocladiopsis irregularis, } \\
\text { murorum var. murorum, Aspergillus fumigatix, } \\
\text { Cylindrocarpon, Podospora sp., Plectosphaerella } \\
\text { cucumerina, Pichia guilliermondii, Neonectria } \\
\text { radicicola }\end{array}$ & {$[6,36,44]$} \\
\hline $\begin{array}{lr}\text { Foeniculum } & \text { vulgare } \\
\text { Lactuca } & \text { sativa, } \\
\text { Cichorium intybus, } & \text { Apium graveolens }\end{array}$ & Acremonium, Alternaria, Fusarium, Plectosporium & {$[14,17]$} \\
\hline Antiaris toxicaria & Trichothecium, acremonium, Rhizoctonia & [11] \\
\hline Iris germanica & Rhizopus oryzae & [61] \\
\hline Saussurea involucrate & Cylindrocarpan sp. Phoma sp., Fusarium sp. & [29] \\
\hline $\begin{array}{l}\text { Dendrobium } \\
\text { devonianum }\end{array}$ & Fusarium sp., Phoma sp., Epicoccum nigrum & {$[58]$} \\
\hline Podocarpus species & Aspergillus fumigates & [59] \\
\hline Hemionitis ariflora & Several endophytic fungi & {$[21,22]$} \\
\hline Oryza granulate & $\begin{array}{l}\text { Dothideomycetes, Arthrinium sp., Magnaporthe sp., } \\
\text { Muscador sp. }\end{array}$ & {$[31,41,46]$} \\
\hline Actinidia macrosperma & $\begin{array}{l}\text { Acremonium furcatum, Cylindrocarpon pauciseptatum, } \\
\text { Trichoderma citrinoviride, Paecilomyces marquandii, } \\
\text { Chaetomium globosum }\end{array}$ & {$[28]$} \\
\hline Solanum cernuum Vell. & $\begin{array}{l}\text { Arthrobotrys foliicola, Colletotrichum gloeosporioides, } \\
\text { Coprinellus radians, Glomerella acutata, Diatrypella } \\
\text { frostii, Phoma glomerata, Mucor sp., Phlebia } \\
\text { subserialis, Phoma moricola, Phanerochaete sordida, } \\
\text { Colletotrichum sp. }\end{array}$ & {$[55]$} \\
\hline
\end{tabular}

\section{PRODUCTION AND OPTIMIZATION OF ENDOPHYTE DERIVED BIOACTIVE COMPOUNDS}

\subsection{Production of bioactive compounds from fungal endophytes}

The symbiotic relationship among endophytic fungi and plants gives powerful ability to produce new bioactive compounds. However, there are main two substrate-based methods for the production of bioactive compounds such as Solid state fermentation and submerged state fermentation $[14,21,56,32,44]$.

\subsubsection{Solid state fermentation (SSF)}

Solid State fermentation is widely used for the bioactive compounds production from the fungal endophytes $[21,31,41,51,55]$. This biomolecules are mostly metabolites generated by endophytic fungi grown on solid support selected for this purpose. In this fermentation process, different solid substrates such as Wheat bran, Rice bran, coconut oil cake, vegetable waste, gram husk, orange peel, sugarcane bagasse etc were used with pure cultures of endophytic fungi $[14,21,56,32,44,50,61]$.

In environment, fungal endophytes breed on the ground; decomposing vegetables combinations under naturally ventilated conditions, Therefore SSF enables the optimal growth of endophytic fungi, permitting the mycelium to spread on the surface of solid compounds through which air can flow $[14,32,59,61]$. SSF uses culture substratum with low water levels. The solid medium contains both the substrates and solid support [21,56]. After fermentation, fermented media are mixed with effective solvent and further used for purification and analysis $[14,32,56,59,61]$. 


\subsubsection{Submerged fermentation}

In submerged fermentation, enzymes and other reactive compounds are submerged in a liquid such as alcohol, oil, or nutrient broth [21,42,24]. Endophytic fungi are sited in a small closed flask containing the rich nutrient broth with high volume of oxygen. The in situ production of enzymes results in production of bioactive molecule $[27,28,35,49,58,60]$. Batch Fed fermentation method is used commonly which utilizes the sterilised nutrients under optimized conditions along with fungal endophytes which increase in density $[23,36]$. The growth rate of fungal endophytes are maintained by the addition of nutrients, also reduces risk of overflow of metabolism $[9,23,36]$.

\subsection{Optimization of production of bioactive compounds from fungal endophytes}

Optimization of both fermentation processes depends on considerations of carbon homes and nitrogen homes, inoculums, phosphorus, organic acids, surfactants, incubation period, temperature, moisture level and $\mathrm{pH}$ level under optimized conditions to achieve greatest production of bioactive compounds from fungal endophytes [13,21,31,33,36,59].

\subsubsection{Effect of different medium}

Effect of the different medium on the production of bioactive compounds were observed $[13,21,31,33,36,59]$.

\subsubsection{Effect of carbon sources}

In order to determine the effect of various carbon sources on the production of bioactive compounds, main sugar was replaced by different carbon sources like cellulose, fructose, lactose, galactose, malt dextrin, mannitol and sucrose in the production media $[13,33,36,59]$.

\subsubsection{Effect of nitrogen sources}

Effect of different organic (beef extract, casein, peptone, malt extract, tryptone, soybean meal) and inorganic $\left(\mathrm{KNO}_{3}, \mathrm{NaNO}_{3}\right.$ and $\left.\mathrm{NH}_{2} \mathrm{CONH}_{2}\right)$ at $1 \%(\mathrm{w} / \mathrm{v})$ as additional nitrogen source were studied $[21,31,36,59]$.

\subsubsection{Effect of inoculum amount}

To study the effect of inoculum on bioactive compounds production, different concentrations $(0.5,1.0,2.0,3.0,4.0$ and $5.0 \%(\mathrm{v} / \mathrm{v}))$ of activated culture were used [13,21,31,33,36,59].

Table 7. Media used for the production of bioactive compounds by fungal endophytes

\begin{tabular}{|l|l|l|l|}
\hline Sr. No & Medium & Conditions & References \\
\hline 1 & Liquid Wickerham medium & $26^{0} \mathrm{C}, 21$ days & {$[21]$} \\
\hline 2 & S $_{7}$ medium & $26^{\circ} \mathrm{C}, 21$ days & {$[36]$} \\
\hline 3 & Minimal medium & $28^{0} \mathrm{C}, 10-14$ days & {$[15,16]$} \\
\hline 4 & Lactose \& Starch Casein broth & $37^{\circ} \mathrm{C}, 120 \mathrm{rpm}, 18$ days & {$[24,31]$} \\
\hline 5 & $\mathrm{M}_{2}$ medium & $28^{0} \mathrm{C}, 124 \mathrm{rpm}, 7$ days & {$[40,43]$} \\
\hline 6 & $\begin{array}{l}\text { C2 broth, Sabourauds broth, PDB, }, \\
\text { MEB }\end{array}$ & $28^{0} \mathrm{C}, 10$ days & {$[21]$} \\
\hline 7 & Nutrient Broth & $30^{\circ} \mathrm{C}, 120 \mathrm{rpm}, 5$ days & {$[2,4,6,8,11,13,21,22,30$} \\
& & $37^{\circ} \mathrm{C}, 120 \mathrm{rpm}, 18$ days & {$[30.31]$} \\
\hline 8 & Liquid fermentation & $30^{\circ} \mathrm{C}, 124 \mathrm{rpm}, 24$ hrs & {$[58]$} \\
\hline 9 & Nutrient Broth & $26^{0} \mathrm{C}, 21$ days & {$[30,31]$} \\
\hline 10 & Corn meal medium & & \\
\hline
\end{tabular}




\subsubsection{Effect of inoculum time}

10-24 h old culture at the interval of $2 \mathrm{~h}$ used as inoculum in order to determine the best suitable inoculum age for maximum production of bioactive compounds [13,21,31,33,36,59].

\subsubsection{Effect of $\mathrm{pH}$ and temperature}

The effect of different $\mathrm{pH}$ ranging from 4.0 to 10.0 observed on of bioactive compounds production. However to study the effect of different temperature, flasks were incubated at different temperatures $\left(20-45^{\circ} \mathrm{C}\right)([13,21,31,33,36,59]$.

\subsection{Phytochemical analysis}

The endophytic fungal extract can further be screened by phytochemical analysis, which serves as a key reserve for evidence on analytical and tangential methodology for the presence of bioactive compounds in the extract.

\subsubsection{Test for Flavonoids}

Test-tube containing 1-2 $\mathrm{ml}$ of fungal crude extract, 5-10 drops of dilute $\mathrm{HCl}$, a piece of Magnesium strips were added and the solution was boiled for few minutes. A reddish pink or dirty brown coloration of solution indicates the presences of flavonoids in the extract $[13,16,23,25,55]$.

\subsubsection{Test for Alkaloids}

The fungal crude extract is evaporated to dryness in boiling water bath. The residue obtained is dissolved in $2 \mathrm{~N} \mathrm{HCl}$. The mixture treated with equal amount of Wagner's reagent. The reaction shows the appearance of brown precipitate, indicates presences of alkaloids $[13,16,23,25,55]$.

\subsubsection{Test for Terpenoids}

$1 \mathrm{ml}$ of fungal crude extract is mixed in $1 \mathrm{ml}$ of chloroform and 3-4 drops of concentrated $\mathrm{H}_{2} \mathrm{SO}_{4}$ were added. A cherry red colour or reddish-brown precipitate at the interface indicates the presence of terpenoids [13,16,23,25,55].

\subsubsection{Test for Cardiac glycosides}

To $1 \mathrm{ml}$ of fungal crude extract, add $1 \mathrm{ml}$ of $\mathrm{FeCl}_{3}$ reagent. To this solution, add few drops of concentrated $\mathrm{H}_{2} \mathrm{SO}_{4}$ were added. Appearance of greenish blue colour within a few minutes indicates the presence of cardiac glycosides $[13,16]$.

\subsubsection{Test for Steroids}

To $1 \mathrm{ml}$ of fungal crude extract, add $1 \mathrm{ml}$ of chloroform and $1 \mathrm{ml}$ of acetic anhydride and little concentrated $\mathrm{H}_{2} \mathrm{SO}_{4}$. A blue green ring indicates the presence of steroids [13,16,23,25,55].

\subsubsection{Test for Saponins}

The crude dry powder of fungal extract was energetically shaken with distilled water and was allowed to stand for $10 \mathrm{~min}$. No froth indicates lack of saponins and stable forth more than $1.5 \mathrm{~cm}$ indicated the presence of saponins $[13,25,55]$.

\subsubsection{Test for Phenols}

The fungal crude extract is dissolved in $5 \mathrm{ml}$ of distilled water. Few drops of neutral $5 \%$ $\mathrm{FeCl}_{3}$ solution was added. A dark green indicates the presence of phenolic compounds $[13,16,23,25,55]$.

\subsubsection{Test for Tannins}

The fungal crude extract treated with alcoholic $\mathrm{FeCl} 3$ reagent. A bluish black colour, which disappears on adding little dilute $\mathrm{H}_{2} \mathrm{SO}_{4}$ followed by the configuration of yellowish brown precipitate, indicates the presence of tannins [13,16,23,25,55]. 


\section{PURIFICATION AND STRUCTURE ELUCIDATION ENDOPHYTE DERIVED BIOACTIVE COMPOUNDS}

Endophyte derived bioactive compounds include a broad diversity of structures and functionalities that provide a greatest pool of molecules for the production of different in-house products $[6,9,13,16,23,35,41,55]$. Many of these compounds can be found at very high concentration in nature while some found to be very low in concentration so that extraction is required to obtain sufficient amounts and their structural diversity and complexity create chemical synthesis unbeneficial $[3,5,7,11,13,14,16,13,23,35,55]$. From long time, Liquidliquid extraction or solid- liquid extraction are used for the extraction purpose but nowadays pressurized liquid extraction, Subcritical \& Supercritical extraction, and ultrasound assisted extraction are highlighted [3,5,7,11,13,14]. Fermented media is exposed to different solvent which takes up compounds of interest which is further centrifuged and filtered to obtain crude extract. Mostly, Hexane, ether, chloroform, acetonitrile, benzene, ethanol and distilled water is used in different proportion [3,5,7,11,13,14,16,13,23,35,55].

Purification is the physical separation of specific substances from contaminating substances. Purification includes mainly filtration, centrifugation, crystallization, distillation, chromatography; electrophoresis etc. While structure elucidation of endophyte derived bioactive compounds determination of chemical composition by NMR, mass spectroscopy, Crystallography, UV-visible spectroscopy etc. [1,2,3,5,7,11,13,14,16,13,17,23,35,55].

Table 8. The use of different solvents extraction for the recovery of endophyte derived bioactive compounds.

\begin{tabular}{|c|c|c|c|}
\hline Solvents used & Raw Material & Compound of interest & References \\
\hline $\begin{array}{l}\text { Ethanol, methanol, } \\
\text { n- hexane }\end{array}$ & $\begin{array}{l}\text { Liquid } \\
\text { Wickerham } \\
\text { medium, solid } \\
\text { rice medium }\end{array}$ & $\begin{array}{l}\text { Alternariol, alteariol } \\
\text { methyl ether, } \\
\text { stemphylperylenol, } \\
\text { bostrycin, Tenuazonic acid, } \\
\text { indole-3, carbaldehyde, } \\
\text { Cyclo } \\
\text { (Threonylisoleucinyl), } \\
\text { Aloesol, Deoxybostrycin, } \\
\text { Equisetin, Citrinin. }\end{array}$ & {$[21]$} \\
\hline $\begin{array}{l}\text { Chloroform, methanol, } \\
\text { n- hexane }\end{array}$ & $\begin{array}{l}\text { Mycological } \\
\text { medium }\end{array}$ & Taxol & {$[36]$} \\
\hline $\begin{array}{l}\mathrm{n} \text { - hexane, chloroform, ethyl } \\
\text { acetate, ethanol, methanol, } \\
\text { butanol, petroleum ether }\end{array}$ & $\begin{array}{l}\text { L.B \& S.C } \\
\text { broth }\end{array}$ & $\begin{array}{l}\text { Alkaloids, phenolic } \\
\text { compounds }\end{array}$ & {$[24,42]$} \\
\hline Water & Plant extract & Triethylene glycol & {$[22]$} \\
\hline Ethanol & PDB & Naphthoquinones & {$[2,44,45]$} \\
\hline Chloroform, ethyl acetate & $\begin{array}{l}\text { Minimal } \\
\text { medium }\end{array}$ & $\begin{array}{l}\text { Flavonoids, Saponins, } \\
\text { Alkaloids, }\end{array}$ & [43] \\
\hline $\begin{array}{l}\mathrm{n} \text { - hexane, chloroform, ethyl } \\
\text { acetate, ethanol, methanol }\end{array}$ & NB & $\begin{array}{l}\text { Pyrrolo, methyl-2-o- } \\
\text { methyla-arabino } \\
\text { pyranoside, } \\
\text { Propionylfilicinic, benzene, } \\
\text { Carboxylic acid. }\end{array}$ & {$[30,59,60]$} \\
\hline Ethanol, methanol & Plant extract & $\begin{array}{l}\text { Flavonoids, Saponins, } \\
\text { Tannins, Terpenoids }\end{array}$ & {$[35,57]$} \\
\hline
\end{tabular}


Table 9. Different purification and structural elucidation techniques for the recovery of endophyte derived bioactive compounds

\begin{tabular}{|l|l|l|l|}
\hline Methodology & Structure elucidation & Compounds of interest & References \\
\hline Purification & NMR, Crystallography & $\begin{array}{l}\text { Steriods, ergosterol, } \\
\text { cerevisterol }\end{array}$ & {$[31,44]$} \\
\hline TLC, HPLC, SGC & GC-MS, NMR & Taxol, Taxane III & {$[45,61]$} \\
\hline TLC, VLC, LC, HPLC & $\begin{array}{l}\text { Ms, ESI-MS, LC-MS, } \\
\text { HRMS, NMR }\end{array}$ & $\begin{array}{l}\text { Alternariol, alteariol methyl } \\
\text { ether, stemphylperylenol, } \\
\text { bostrycin, tenuazonic acid, } \\
\text { indole-3, carbaldehyde, cyclo } \\
\text { (Threonylisoleucinyl), } \\
\text { aloesol, deoxybostrycin, } \\
\text { equisetin, citrinin }\end{array}$ & {$[21]$} \\
\hline TLC, VLC, HPLC & GC-MS, NMR & Shamiminol & \\
\hline TLC, CC, HPLC & NMR, ESI-MS & $\begin{array}{l}\text { Cytochalasin J, cytochalasin } \\
\text { H, 5- epialtenuene alternariol } \\
\text { monomethylether alternariol, } \\
\text { cytosporone C }\end{array}$ & {$[4,5]$} \\
\hline TLC, HPLC & NMR & Resaveratrol & {$[2,58]$} \\
\hline HPLC & $\begin{array}{l}\text { ESI-MS, NMR, TOF- } \\
\text { MS }\end{array}$ & Gold nanoparticles & {$[34,42]$} \\
\hline TLC, CC, HPLC & GC-MS, NMR & Teadenol A & {$[61]$} \\
\hline TLC,UV-VS & GC-MS, NMR & Alkaloids & {$[22,41]$} \\
\hline
\end{tabular}

\section{NOVEL FUNGAL ENDOPHYTES VERSES NOVEL BIOACTIVE COMPOUNDS}

Discovering novel bioactive compounds from undiscovered endophytes is current trend. Not all endophytes are culturable $[47,48]$ and these may produce useful bioactive metabolites. There are numerous techniques to detect unculturable fungi and these include whole DNA analysis monitored by DNA cloning, DGGE or T-RLFP $[34,41,42,43]$. Therefore, apart from isolating culturable endophytes from different taxonomic groups of plants and plants growing in different habitats, shotgun metagenomics for endophyte community analysis and functionbased screening of their metagenomics libraries could be used to harness the unculturable and truly cryptic endophytes from environmental samples for drug production. Such a metagenomics approach has been quite rewarding with soil samples [4,5,24,50]. Metabolomics of endophyte infected and endophyte free plant hosts could reveal intersections in secondary metabolite paths that may be pushed into synthesizing novel chemical species or lead compounds another possibility of manipulating these chemo diverse organisms [50,51,60]. Additionally, other novel techniques such as radiochemical labelling can be used for detecting products of genes with low expressions among endophytes (Lodge et al. 1996). In addition, the biological potential of fungal secondary metabolites could also be fully realized by the application of combinatorial techniques [23,46,47,51].

In fungal endophytes, genes coding for enzymes of secondary metabolic pathways usually occur as gene clusters being positioned in the same locus and co-expressed [23]. These gene clusters are known to evolve swiftly through multiple rearrangements, duplication and losses, and are capable of interspecific feast through horizontal gene transfer [25,27,40]. It is important to screen fungal species for their secondary metabolite assortment under different growing conditions; culture parameters such as composition of growth medium, aeration, $\mathrm{pH}$ and the 
presence of certain enzyme inhibitors change vividly the secondary metabolite profile and even induce the synthesis of several new metabolites $[8,9,21,31,35,44]$.

As far as drug discovery is concerned, screening of libraries created by combinatorial combination once appeared to be more hopeful than natural products screening $[13,58]$. Though combinatorial synthesis can churn out molecules in enormous numbers, endophytic fungi can still be a good source of novel drugs and natural product-based scaffolds for combinatorial synthesis and libraries [56]. This is because the synthetic capability of endophytes, like in other organisms, has been fine tuned by natural selection over millions of years. Smith et al. (2008) united sequence analysis with bioassay procedures to explore the endophyte diversity of the tropics. Their results suggest that tropical plants harbour a substantial portion of undiscovered endophytes that may be vested with novel biochemical diversity. Hence, the need for the inclusion of fungal endophytes in natural products discovery programmes. Testing endophytes isolated from different tissues of plant hosts and from plants, growing in unusual and less studied habitats will be more productive. We suggest a global initiative involving fungal taxonomists, ecologists, and natural product chemists to evolve systematic and rapid screens for endophytic fungi by scheming considered bioassays that would indicate the production of novel bioactive compounds [11-14,16,23,25,35,46,55].

\section{CONCLUSION}

Isolation of fungal endophytes from medicinal and other plants may result in methods to produce biologically active agents for biological exploitation on a large commercial scale, as they are easily cultured in laboratory and fermenter instead of harvesting plants and affecting the eco-friendly biodiversity.

\section{ORCID}

Ankala Basappa Vedamurthy (iD) https://orcid.org/0000-0002-3101-0629

\section{REFERENCES}

[1]. Aditi, M., Arjun, V., Gayathri, M. (2017). A Brief Review on Medicinal Plants from South India, Endophytes and their Antidiabetes Properties. International Journal of Current Research, 9, 1- 4.

[2]. Agusta, A., Ohashi, K., and Shibuya, H. (2006). Composition of the endophytic filamentous fungi isolated from the tea plant Camellia sinensis. Journal of Natural Medicine, 60, 268272.

[3]. Ananda, K., Shridhar, K. (2002). Diversity of endophytic fungi in the roots of mangrove species on west coast of India. Canadian Journal of Microbiology, 48, 871-878.

[4]. Anisworth, C., Sparrow, K., Sussaan, S. (1973). The Fungi? Advanced Treaties, Taxonomic review with keys. Academic Press, New York, USA.

[5]. Ashour, M., Hany, Y., Peter, M. (2011). Utilization of agro industrial by products for the production of bioactive natural products from endophytic fungi. Journal of Natural Product, 4, 108-114.

[6]. Arun, G., Robert, A., Rajesh, V. (2015). Exploration of endophytic microorganisms from selected medicinal plants and their control potential to multi drug resistant pathogens. Journal of Medicinal Plant Studies, 3, 49-57.

[7]. Ananda, K., and Shridhar, K. (2002). Diversity of endophytic fungi in the roots of mangrove species on west coast of India. Canadian Journal of Microbiology, 48, 871-878. 
[8]. Bills, G. (1996). Isolation and Analysis of endophytic fungi fungal communities from woody plants, American Phytopathological Society press.

[9]. Bode, B., Bethe, B., Hofs, R., Zeek, A. (2002). Big effects from small changes: possible ways to explore nature's chemical diversity. Biochem, 3, 619-627.

[10]. Bok, W., Noordermeer, D., Kale, S., Keller P., (2006). Secondary metabolic gene cluster silencing in Aspergillus nidulans. Molecular Microbiology, 61, 1636-1645.

[11]. Carroll, G., Carroll, E. (1978). Studies on the incidence of coniferous needle endophytes in the Pacific North West, USA. Canadian Journal of Botany, 56, 3034-3043.

[12]. De Barry, A. (1879). Die Erscheinung der Symbiose. In: Trubner KJ, ed. Vortrag auf der Versammlung der Nature forscher und Ärtze zu Cassel. Strassburg, Germany, Verlag, 13.

[13]. Devi, N., Prabakaran, J., Wahab, F. (2012). Photochemical analysis of an enzyme analysis of endophytic fungi from Cantella asiatica. Asian journal of tropical biomedicine, 23, S1280-S1284.

[14]. D'Amico, M., Frisullo, S., Cirulli, M. (2008). Endophytic fungi occurring in fennel, lettuce, chicory, and celery-commercial crops in southern Italy. Mycological Research, 112, 100-107.

[15]. Dai, W., Zhang, H., Huang, G., Dai, F., Mei, L. (2009). Isolation, Identification, and antimicrobial activity of endophytic fungi from Antiaris toxicaria. Chinese Traditional and Herbal Drugs, 40, 955-957.

[16]. Fisher, J., and Petrini, O. (1992). Fungal saprobes and pathogens as endophytes of rice (Oryza sativa L.). New Phytologist, 120, 137-14.

[17]. Garg, N., Meena, A., Nain, J. (2011). Evaluation of physicochemical and preliminary phytochemical studies on the root of Bombax ceiba Linn. International Journal of Research in Pharmacy, 2, 924-926.

[18]. Gamboa, A., Bayman, P. (2001). Communities of endophytic fungi in leaves of a tropical timber tree (Guarea Guidonia: Meliaceae). Biotropica, 33-35.

[19]. Higgins, L., Arnold, E., Coley, D., Kursar, A. (2014). Communities of fungal endophyte in tropical forest grasses: highly diverse host- and habitat generalists characterized by strong spatial structure. Journal of Biology, 23, 234-241.

[20]. Jacob, F. (1985). The true story of penicillin, Dodd Mead and Company, New work.

[21]. Jaspreet, N., Ajay, M., Nikita, G., (2011). Evolution of physicochemical and preliminary phytochemical studies as the root of Bombax ceiba Linn. International Journal of Research in Ayurveda and pharmacy, 2, 924-926.

[22]. Julia, K. (2009). New Natural Products from Endophytic Fungi from Mangrove PlantsStructure Elucidation and Biological Screening. Heinrich-Heine University. PhD Thesis.

[23]. Karmakar, J., and Mukhopadhyay, K. (2011). Study of antimicrobial activity and root symbionts of Hemionitis arifolia. Physiology and Molecular Biology of Plants, 17, 199202.

[24]. Keller, P., Hohn, T. (1997). Metabolic pathway gene clusters in filamentous fungi. Fungal Genetics and Biology, 21, 17-2.

[25]. Kumanand, T., Meenakshi, S., Paran, B. (2012). Endophytic Fungi occurring in Ipomoea carnea Tissues and their Antimicrobial potentials. International Journal of Brazilian archives of Biology and Technology, 12, 234-243.

[26]. Li, J., Zhao, J., Xu, L., Zhou, L., Li, X., Wang, J. (2008). Endophytic fungi from rhizomes of Paris polyphylla var. Yunnanensis. World Journal of Microbiology and Biotechnology, 24, 733-737. 
[27]. Larran, S., Monaco, C., and Alippi, E. (2001). Endophytic fungi in leaves of Lycopersicon esculentum Mill. World Journal of Microbiology and Biotechnology, 17, 181-184.

[28]. Lodge, D., Fisher, J., Sutton, C. (1996). Endophytic fungi of Manilkara bidentate leaves in Puerto-Rico. Mycologia, 88, 733-738.

[29]. Lu, H., Xou, W., Meng, C., Hu, J., and Tan, R. (2000). New bioactive metabolites produced by Colletotrichum species an endophytic fungus in Artemisia annua. Plant Science, 151, 67-73.

[30]. Lv, Y., Zhang, F., Chen, J., Cui, J., Xing, Y., Li, X., Guo, S. (2010). Diversity and antimicrobial activity of endophytic fungi associated with the alpine plant Saussurea involucrate. Biological and Pharmaceutical Bulletin, 33, 1300-1306.

[31]. Mane, R., Shinde, M., Wagh, P., Malkar, H. (2017). Isolation of Endophytic microorganisms as a source of novel secondary metabolite producers against Tuberculosis. International Journal of Science and Research Technology, 3, 1267-1269.

[32]. Mane, R., and Vedamurthy, A. (2018). The fungal endophytes: Sources and future prospects. Journal of Medicinal Plants Studies, 6, 121-126.

[33]. Mitchell, A., Strobel, G., Hess, W., Vargas, P., and Ezra, D. (2008). A novel endophyte from Ananas ananassoides in the Bolivian Amazon. Fungal Diversity, 31, 37-43.

[34]. Mittermeier, R., Meyers, N., Gil, P., Mittermeier, C. (1999). Hotspot: Earthes Biologically Richest and Most Endangered Ecoregions, Washington DC, CEMEX Conservation International.

[35]. Murthy, N., Lakshman, H., Pushplatha, K., Jambagi, R. (2010). Biodiversity of endophytic fungi isolated from selected graminaceous hosts of Mercara region in Karnataka. International Journal of Plant Protection, 3, 335-341.

[36]. Nayantara, A., Amrita, S., Rashmi, K., Arun, S., Arun, K., Bhavesh, D., Sheila, R. (2011). Potential antibacterial and antifungal activity of aqueous extract of cynodon dactylon. International Journal of pharmaceutical sciences and research, 2, 2889-2893.

[37]. Pandi, M., Manikandan, R., Muthumary, J. (2010). Anticancer activity of fungal taxol derived from Botryodiploda theobromae Pathogens. Biomedicine and Pharmacotherapy, 64, 1, 48-53.

[38]. Petrini, O., Müller, E. (1979). Endophyte as Beispiel von Juniperus communis L. Sydowia, 32, 224-225.

39]. Prior, Rene. (2016). New Isolation methods for endophytes based on enzyme digestion. Mycological progress, 3, 1-8.

[40]. Raghu, K. (2008). Marine fungal biotechnology: an ecological perspective. Fungal Diversity, 31, 19-35.

[41]. Raper, K., Thom, C. (1949). A Manual of the penicillin, Biomedical Press, 34, 278-287.

[42]. Rodrigues, R., White, J., Arnold, A., and Redman, R. (2008). Fungal Endophytes: diversity and function area. Tansley review, 23, 1-17.

[43]. Rodrigues, K. (1994) the foliar fungal endophytes of the Amazonian palm Euterpe olerace. Mycologia, 86, 376-385.

[44]. Sette, L., Passarini, M., Delarmelina, C., Salati, F., and Duarte, M. (2006). Molecular characterization and antimicrobial activity of endophytic fungi from coffee plants. World Journal of Microbiology and Biotechnology, 22, 1185-1195.

[45]. Shankar, B., Shashikala, J., Krishnamurthy, Y. (2008). Diversity of fungal endophytes in shrubby medicinal plants of Malnad region, Western Ghats, Southern India. Fungal Ecology, 1, 89-93. 
[46]. Smith, S., Tank, D., Boulanger, A., Bascom-Slack, C., Eisenman, K., David Kingery, D., Babbs, B., Fenn, K., Greene, J., Hann, B., Keehner, J., Kelley-Swift, E., Kembaiyan, V., Lee, J., Li, P., Light, D., Lin, H., Ma, C. (2008). Bioactive endophytes warrant intensified exploration and conservation. Canadian Journal of Botany, 66, 45-54.

[46]. Stone, J., Petrini, O. (1997). Endophytes of forest trees: a model for fungus-plant interactions. The Mycota, 26, 129-140.

[47]. Stone, J., Polishook, J., White, J. (2004). Endophytic fungi. Biodiversity of Fungi, 21, 241-270.

[48]. Strobel, G., Daisy, B. (2003). Bio prospecting for microbial endophytes and their natural products. Microbiology of Molecular Biology, 67, 491-502.

[49]. Suthep, W., Nongluksna, S., Wattana, P., Nuntawan, T., Kannawat, D., Nijsiri, R., and Vithaya, M. (2016). Biology of Fungi. World Journal of Microbiology \& Biotechnology, 20, 265-272.

[50]. Suryanarayanan, T., Kumaresan, V. (2002). Endophytic assemblage in young, mature and senescent leaves of Rhizophora apiculate: evidence for the role of endophytes in mangrove community. Fungal diversity, 9, 81-91.

[51]. Suryanarayanan, S. (2011). Diversity of fungal endophytes in tropical trees. Endophytes of Tropical Trees. Forestry Sciences Series, 80, 67-80.

[52]. Tian, X., Cao, L., Tan, H., Zeng, Q., Jia, Y., Han, W., and Zhou, N. (2004). Study on the communities of endophytic fungi and endophytic Actinomycetes from rice and their antipathogenic activities In vitro. World Journal of Microbiology and Biotechnology, 20, 303-309.

[53]. Tiwari, K. (2015). The future products: Endophytic fungal metabolites. Journal of Biodiversity, Bio prospecting and Development, 2, 2-7.

[54]. Verma, V., Gond, S., Kumar, A., Kharwar, R., Strobel, G. (2007). The endophytic mycoflora of bark, leaf, and stem tissues of Azadirachta indica A. Juss (Neem) from Varanasi (India). Microbial Ecology, 54, 119-125.

[55]. Vieira, M., Hughes, A., Gil, V., Vaz, A., Alves, T., Zani, C., Rosa, C., Rosa, L. (2012). Diversity and antimicrobial activities of the fungal endophyte community associated with the traditional Brazilian medicinal plant Solanum cernuum Vell. (Solanaceae). Canadian Journal of Microbiology, 58, 54-66.

[56]. Wang, F., Jiao, R., Cheng, A., Tan, S., and Song, Y. (2006). A Antimicrobial potentials of endophytic fungi residing in Quercus variabilis and brefeldin A obtained from Cladosporium species. World Journal of Microbiology and Biotechnology, 104, 124-134.

[57]. Wilson, D., Carroll, G. (1994). Infection studies of Discula quercina, an endophyte of Quercus garryana. Mycologia, 86, 635-647.

[58]. Xing, M., Chen, J., Cui, J., Chen, X., Guo, S. (2011). Antimicrobial activity and biodiversity of endophytic fungi in Dendrobium devonianum and Dendrobium thyrsiflorum from Vietnam. Current Microbiology, 62, 1218-1224.

[59]. Yuan, Z., Su, Z., Mao, L., Peng, Y., Yang, G., Lin, F., Zhang, C. (2011). Distinctive endophytic fungal assemblage in stems of Wild Rice (Oryza granulata) in China with special reference to two species of Muscodor (xylariaceae). Journal of Microbiology, 49, $15-23$.

[60]. Zia, U., Sheraz, A., Nazish, V., Sajjad, H., Saima, G., Sabir, K., Pir, M., Shabhum, S. (2012). Nutritional potential and antioxidant activity of Solanum nigrum and Oenothera speciose from Northern area of Pakistan. Internatinal Journal of Biological and Pharmaceutical research, 3, 974-979. 
[61]. Zuccaro, A., Lahrmann, U., Guldener, U., Langen, G., Pfiffi, S., Biedenkopf, D., Wong, P., Samans, B., Grimm, C., Basiewicz, M., Murat, C., Martin, F., Kogel, K. (2011). Endophytic life strategies decoded by genome and transcriptome analyses of the mutualistic root symbiont Piriformospora indica. PLoS Pathogens, 7, 123-129. 